\title{
RECURSOS POTENCIAIS DE GRUPOS CAÇADORES-COLETORES NO MÉDIO RIO RIBEIRA (SP): ESTUDOS FITOSSOCIOLÓGICOS. Nota Preliminar
}

Estudos fitossociológicos realizados em duas áreas no domínio das florestas tropicais no Médio Vale do Rio Ribeira mostram que a regiāo apresenta grande homogeneidade ecológica, embora haja diferenças locais. As condiçōes micróclimáticas e topográficas da região eram propícias para o assentamento de grupos caçadores-coletores que dispunham de uma variedade ampla de recursos vegetais existentes (notadamente frutos) de diversas épocas do ano.

\section{Materiais e métodos}

O método utilizado para a análise da vegetação foi o de quadrantes (Cottam \& Curtis, 1956), que consiste no estabelecimento, dentro da formação estudada, de pontos ao acaso

A. dendrograma de classes de altura

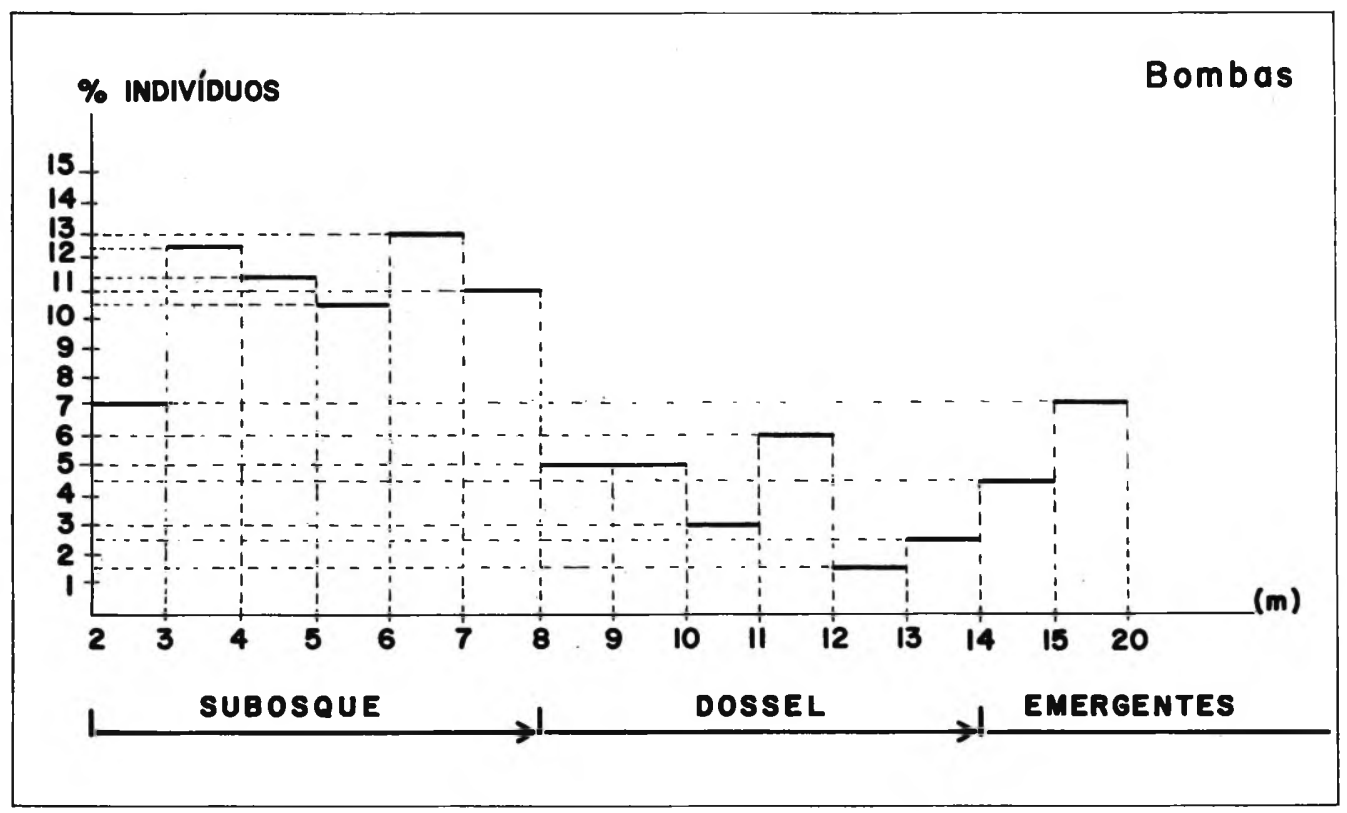


que funcionam como centros de círculos divididos em quatro partes ou quadrantes (Martins, 1978). Em cada quadrante foi amostrado o indivíduo mais próximo do centro do círculo. De cada individuo, foram anotados a espécie, quando conhecida, a altura, o perimetro, a sua distância do ponto de amostragem, além da coleta do material botânico, para posterior identificação das espécies não conheci- das em campo. Este material foi prensado, seco em estufa e encontra-se, em parte, em processo de identificação.

A partir dos dados de campo foram elaborados dendrogramas de classes de altura, com intervalos de $1 \mathrm{~m}$ (ver figuras A e B).

Walter Mareschi Bissa* Waldir Mantovani**

\section{B. DENDROgRAMA de classes de ALtURA}

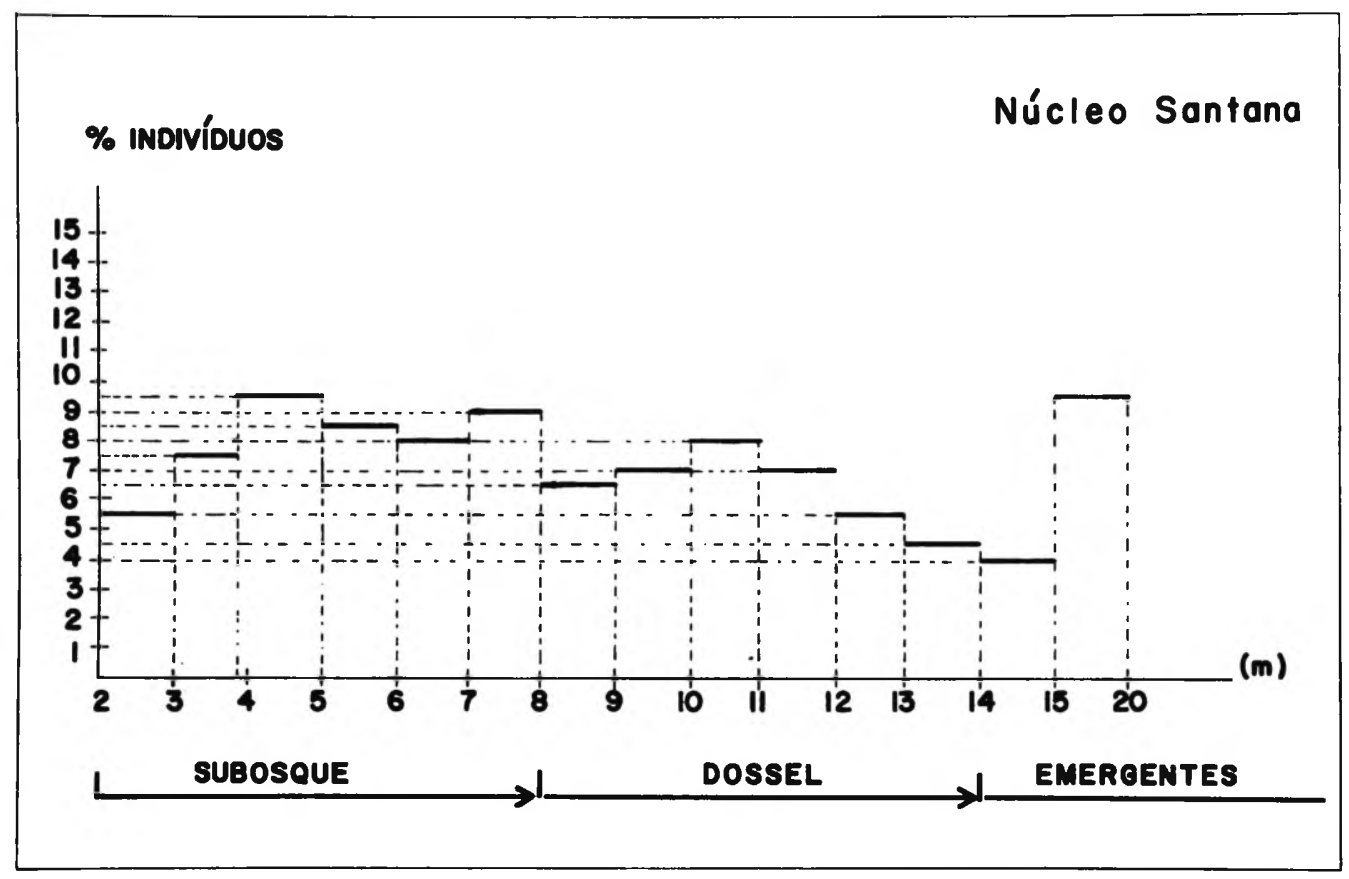

\section{Referências bibliográficas}

COTTAM, G.\& CURTIS, J.T. The use of distance measures in phytosociological sampling. Ecology, 37(13):451-460, 1956.

MARTINS, F.R. Critérios para avaliaçāo de recursos

Recebido para publicação em 7 de julho de 1992. naturais. In: Simpósio sobre a Comunidade Vegetal como Unidade Biológica, Turística e Econômica. Anais, Sāo Paulo, Publicaçōes ACIESP 5:136. 149, 1978.

(*) Museu de Arqueologia e Etnologia da Universidade de São Paulo.

(**) Departamento de Ecologia Geral do Instituto de Biociências da Universidade de São Paulo. 